\title{
Learning Motivation of Students in Teaching Indonesian to Speakers of Other Language in Manila
}

\author{
Fabio Testy Ariance Loren \\ \{fabioloren@umrah.ac.id\} \\ Universitas Maritim Raja Ali Haji, Tanjungpinang City, 29115, Indonesia
}

\begin{abstract}
Learning motivation is one of the factors influencing language learning achievement and its continuity. This means understanding the motivation of learners is required to improve language learning. Therefore, this study aims to describe and explain the types of motivation associated with Teaching Indonesian to Speakers of Other Language (TISOL) learners in Manila, Philippines. A naturalistic case study was used with the data collected through observation and in-depth interview while the samples were selected using the purposive sampling technique. The findings showed there are two types of motivation for TISOL learners in Manila and these include external and internal motivation. The external aspect indicates the use of the Indonesian language in all the regions of Indonesia and several neighboring countries as well as the need to preserve the country's culture and the similarities between the vocabularies of Tagalog and Indonesian languages. Meanwhile, the internal aspect includes the opportunity it provides to work with Indonesians, the willingness to gain knowledge and have new friends, and the ability to communicate with locals when traveling to Indonesia.
\end{abstract}

Keywords: TISOL, motivation, Manila.

\section{Introduction}

Indonesian language (hereinafter referred to as Bahasa) is the language of unity in Indonesia. It acts as a means of communication and also has a noble function and meaning because it contains national values and dignity which serve as the ideology of the Indonesian people. Moreover, one of the objectives of the country is to propose Bahasa as an international language based on the significant increase in the number of foreigners willing to learn the language. Therefore, a language learning course which is called TISOL (Teaching Indonesian to Speakers of Other Languages) has been designed by Indonesia for foreigners (Kusmiatun: 2016).

The language has become popular through these kinds of programs implemented in 29 countries in the form of the 420 BIPA (Suparsa et al., 2017), thereby, leading to the placement of Bahasa on the 4th position among the largest spoken languages in the world. For example, the local government of Ho Chi Minh City in Vietnam has officially designated Bahasa as the second foreign language while it has become the fourth most popular language in other countries such as Australia. Moreover, the BIPA learning program is one of the diplomacy strategies used in disseminating and presenting Bahasa as an international language (Jun, Hung, When, Chen, \& Aldeehani, 2019). 
The Indonesian language learning program for foreign speakers is a facility provided by the Indonesian government to teach foreign learners interested in learning the language (Warsono, Budyanto, \& Ridwan, 2019, \& Runtuwarouw, 2019), especially those from the neighboring countries in Southeast Asia. For example, Bahasa is currently being studied in eight universities in the Philippines including the University of the Philippines, Philippine Normal University, Ateneo de Manila, Mirriam College, Perpetual Help System Dalta, Philippine Women's University, Far Eastern University, and the Polytechnic University of the Philippine. Moreover, PPSDK collaborated with the Indonesian Embassy in Manila to open a public class for Filipinos to learn Bahasa free of charge. It has also been sending TISOL teachers to Manila for three years. In the first year, only one teacher was sent but the number was increased to two in the second year, and three in the third year. Therefore, the focus of this research is to determine the motivations of TISOL students in the Philippines based on the higher demand for teachers every year. This is required to improve the learning process in line with the motivation of the students in order to ensure more people in the Philippines are interested in learning Bahasa.

Motivation has been conceptualized from different perspectives, it has been presented as an inner force, a long-lasting nature, behavioral responses to stimuli, and several collections of individual beliefs and emotions. It has also been defined as a process of initiating and maintaining certain activities to achieve goals (Schunk, et al, 2012: 6). Moreover, the motivation to learn is required to ensure optimal development of self-abilities to perform better, excel, and be creative (Maslow in Nashar, 2004: 42).

Clayton Alderfer (in Nashar 2004: 42) defined learning motivation as an internal and external impulse which causes an individual to act or achieve certain goals, thereby, leading to a change in behavior. This was supported by the opinion of Suprijono (2014: 163) that learning motivation provides internal and external encouragement to students learning to make behavioral changes. This means good motivation usually leads to satisfying results. It is important to note that the finding of this study is expected to become a reference to developing TISOL in the Philippines, especially Manila.

\section{Methods}

This is a descriptive qualitative study conducted through a case study method and this kind of research normally produces data in the form of words from an analyzed document (Bogdan and Taylor in Moleong, 2013: 4). Moreover, the data obtained were validated through the triangulation of methods and sources while the samples were selected using the purposive sampling technique. The criteria for selection include being a position to provide in-depth information relating to the issues being researched (Neuman, 2000: 198). This led to the selection of TISOL students and teachers in Manila, the Philippines as in the informants.

Data were collected through observation, interview, and document (Creswell, 2007: 129). The interview used in this study was unstructured to avoid limiting the informants to "yes" or "no" answers, ensure the responses are more accurate, and allow the informants to express themselves freely (Riduwan, 2007). Moreover, the data were analyzed using an interactive model which involves data reduction, presentation, drawing conclusions, and data verification 
(Sutopo, 2006: 120). This research was conducted for 3 months in several universities offering the TISOL program in Manila.

\section{Results And Discussion}

Clayton Alderfer (in Nashar 2004:42) defined learning motivation as an internal and external drive which causes a person to act or achieve certain goals, thereby, leading to the expectation of behavioral changes. The findings from the research conducted are stated in the following subsections.

\subsection{External Motivation}

The collection of data from TISOL students in the Philippines through observations and interviews was followed by data reduction. It was observed that the students in the TISOL level A1 class were curious as indicated in the following excerpt.

"When the learning program began, the instructor explained in general about Indonesia and Bahasa. Then, during the explanation, there was a student who raised hand to ask a question by giving a sign. The student (Respondent RO) asked the instructor whether Bahasa could be used anytime and anywhere in Indonesia. The instructor explained that Bahasa is a national language and the identity of Indonesia and this means every Indonesian can speak Bahasa. The student further explained that not everyone can speak Tagalog in the Philippines because every region has its own language".

This means the possibility of using Bahasa Indonesia in all regions of the country is a motivation for students to learn the language, unlike the Tagalog language which is understood only in some places. The other motivations observed among the TISOL students in level A2 are indicated in the following excerpt.

"Student (Respondent DA) introduced himself using Bahasa and was quite fluent considering the fact that he is in level A2. He has lived in Malaysia for several years due to his parent's migration and wanted to learn Bahasa because the language can be used in several neighboring countries such as Malaysia, Vietnam, Southern Thailand, and some regions of Brunei Darussalam".

This indicates the TISOL students are motivated to learn Bahasa due to its use in several neighboring countries outside Indonesia such as Malaysia, Vietnam, Southern Thailand, and Brunei Darussalam. Moreover, the following excerpt also indicates another motivation which leads the B1 TISOL student to learn the language.

"Two TISOL students at BI level seemed to be debating why Indonesia after colonization era still holds firmly to its culture for so long. Another student from the Southeast Asia department explained to others that Indonesia was colonized only for its economy and it did not affect its cultural systems. Therefore, culture in Indonesia is still well preserved." 
This shows that the continuous preservation of culture in Indonesia is another motivation for the TISOL students to learn Bahasa. The students majoring in Southeast Asia understand the history and culture of Indonesia effectively and this increases their willingness to learn the language. It is important to note that the interview conducted with one TISOL student in level A2 showed that the motivation to learn Bahasa is also associated with the several similarities between its vocabularies and those of Tagalog. This significantly motivated the students to speak Bahasa because it becomes easier to learn as indicated from the excerpts of the interview as follows.

Teacher: "Ma'am, why do you continue studying Bahasa up to level A2?"

Respondent (R): "Because many Bahasa and Tagalog words are similar, Ma'am. For

example, you are welcome, door, umbrella, eye, ear. So, it's easier."

\subsection{Internal Motivation}

The internal motivation of the TISOL students was also assessed and the opinion of $\mathrm{SB}$ respondent that was in the previous program at level A1 and also continued to level A2 is indicated in the following interview excerpt.

Teacher : Ma'am, why do you continue studying Indonesian up to A2 level?

SB $\quad$ : Because I can work with Indonesian people. For example, I have visited Indonesia with my dance groups and also to other countries. I think that being able to speak in the country's language is better.

This means the opportunity to work with Indonesian people is one of the motivations for the students to learn Bahasa. Moreover, another A1 level respondent showed that the motivation was to acquire knowledge and meet new friends. This is observed from the following interview excerpt.

Teacher : Ma'am, why do you want to learn Bahasa?

MJ : Because I want to acquire new knowledge and have new friends. Yes, learning Bahasa is fun

It was also discovered that the motivation is higher when the students already have friends from Indonesia as indicated by the following interview excerpt.

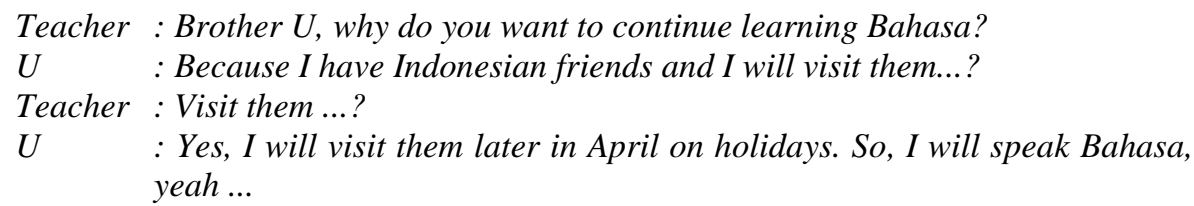

Further findings showed that the students are motivated to learn Bahasa in order to have the ability to communicate effectively with other people during their trip to Indonesia in order to make the trip more fun and easier. This is evident in the following interview excerpt.

Teacher : Ma'am, why do you want to learn Indonesian?

JM : Because we want to travel to Indonesia and communicate while in the country. 


\section{Teacher : When will you go to Indonesia, Ma'am? \\ JM : As soon as I can speak Bahasa.}

The influence of the teacher on the learning process was found to be another motivation for the students. This is observed from the statement of Respondent $\mathrm{N}$ that participated in level A1 and remained consistent in terms of attendance as follows.

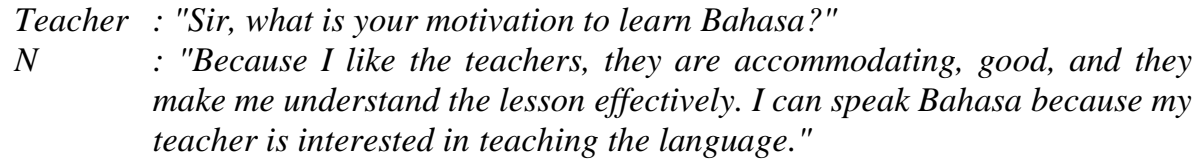

The findings showed that the motivation to learn Bahasa is related to the situations inside and outside the TISOL students in the Philippines and these were categorized as internal and external motivations, respectively. The external motivations include the common use of Bahasa throughout Indonesia despite the existence of different local languages in different regions of the country. This is, however, contrary to the situation in the Philippines where Tagalog which is the national language cannot be used in all regions of the country, thereby, making most of the Filipinos prefer using the English language to communicate.

Another external motivation is the possibility of using Bahasa in several neighboring countries such as Malaysia, Brunei, Thailand, and Vietnam due to the fact that Indonesia is one of the Southeast Asian countries with the largest population and culture. It also has attractive tourist attraction centers which are increasingly demanded by foreign tourists. Therefore, language becomes one of the factors harmoniously connected with Indonesia.

The continuous preservation of culture from the colonial period to the present time is another external motivation for the BIPA students in Manila to learn Bahasa. This was observed from the TISOL students interested in learning Indonesian culture because it was not affected by colonization. Moreover, it is also important to note that interaction is very vital to the process of learning a new language and culture (Rivers, 1987: 5) and this was discovered to be a great motivation for the students because learning the language is inseparable from the Indonesian culture which serves as the national identity.

The examples of the similarities in the vocabularies associated with Tagalog and Bahasa languages that triggered the TISOL students to learn Bahasa are stated as follows. 
Table 1. Similarities in the vocabularies

\begin{tabular}{ll}
\hline Indonesian & Philippine \\
\hline aku & ako \\
payung & payong \\
batu & bato \\
sama & sama \\
pintu & pinto \\
kanan & kanan \\
mahal & mahal \\
anak & anak \\
murah & mura
\end{tabular}

The similarity is due to the fact that Tagalog is an Austronesian language which is included in the Malay proto-language, and the existence of several common words makes it easier for Filipinos to learn Bahasa.

One of the internal motivations associated with the learning of Bahasa is the opportunity to work with Indonesian people. This is based on the assumption of the students that learning the language will be useful in future employment. Another internal motivation is to gain more knowledge and have new friends and this increases when the students have friends from Indonesia. Moreover, the desire for security and comfort physically and psychologically when the students visit Indonesia for a tour is another motivation due to the belief that the mastery of the local language will make the whole trip easier.

The last internal motivation is associated with the ability of the teachers to make the students more interested in learning Bahasa. This is in line with the findings of Oliva (2009: 348 ) that lecturers in higher education need to have some expertise such as the ability to (1) speak, (2) understand words, (3) use correct grammar and sentence structure, (4) read students' facial expressions, (5) maintain interest, (6) pay attention to content with past and future experiences of students, (7) speak publicly, (8) deal with individuals causing disturbances, (9) stimulate thinking, and (10) organize thoughts. This signifies TISOL teachers which are university lecturers have an important role and their expertise can be assessed through the learning process and the skills acquired by the students after the learning process.

A previous study by Randi Ramliyana in 2016 focused on learning motivation for BIPA students, however, it is different from this present study in terms of the object of the research. Moreover, it used comic media to describe ways of improving the motivation to learn Bahasa for foreign speakers while this study describes different types of learning motivation possessed by TISOL students in the Philippines. 


\section{Conclusions}

The findings and discussion showed that motivation is a process of maintaining the activities directed towards achieving certain goals and ensuring optimal development of one's abilities. The learning motivations of TISOL students in Manila were divided into two, internal and external. The results showed the possibility of adjusting the learning process to the motivation of the student in order to improve and ensure the sustainability of TISOL learning programs in Manila.

\section{References}

[1] Creswell, J.W.: Qualitative \& Research Design: Choosing Among Five Approaches Second Edition. New York: Sage Publication, Inc. (2007)

[2] Jun, Ooi Ee, Daisy Kee Mui Hung, Tan Xiang Wen, Koay Xiem Chen, Ma Jia Qi, Faisal AlDeehani.: Issues of Entering New Market and Ways to Overcome the Issues Company: F\&N Holdings Berhad. Asia Pacific Journal of management and education. (2019)

[3] Kusmiatun, A.: Mengenal BIPA (Bahasa Indoensia bagi Penutur Asing ) dan Pembelajarannya. Yogyakarta: K-Media. (2016)

[4] Moleong, Lexy J.: Metodologi Penelitian Kualitatif (Edisi Revisi). Bandung: Remaja Rosdakarya. (2013)

[5] Nashar.: Peranan Motivasi dan Kemampuan Awal dalam Kegiatan Pembelajaran. Jakarta: Delia Press. (2004)

[6] Neuman, W. L.: Social Research Methods: Qualitative and Quantitative Approaches Fourth Edition. New York: Allyn and Bacon. (2000)

[7] Olivia, P.F.: Developing The Curriculum. United States of America: Pearson Education. (2009)

[8] Ramliyana, Randi.: Membangkitkan Motivasi Belajar Bahasa Indonesia Bagi Penutur Asing (BIPA) Melalui Media Komik. Jurnal Dialektika, 3 (1), 1-19. (2016)

[9] Riduwan.: Skala Pengukuran Variabel-Variabel Penelitian. Bandung: Alfabeta. (2007)

[10] Rivers, W.M.: Interactive Language Teaching. New York: Cambridge University Press. (1987)

[11] Runtuwarouw, Roddy Albert.: The Motivation to Work and Environmental Influences Working Performance of the Employment at Department of Education, Youth and Sports District Minahasa. Asia Pacific Journal of management and education. (2019).

[12] Suparsa, I. N., Mantra, I. B. N., \& Widiastuti, I. A. M. S.: Developing learning methods of Indonesian as a foreign language. International Journal of Social Sciences and Humanities, 1(2), 51-57. (2017)

[13] Sutikno, M. Sobry.: Rahasia Sukses Belajar dan Mendidik Anak. Mataram: NTP Press. (2007)

[14] Sutopo, H. B.: Metodelogi Penelitian Kualitatif. Surakarta: UNS Press. (2006)

[15] Warsono, Heribertus Yudho, Budiyanto, Akhmad Riduwan.: Analysis of Educators' Work Motivation in Supporting Main Tasks of Development and Education Command of Indonesian Navy (Causal Study in Educators Group Kobangdikal, Surabaya). Asia Pacific Journal of management and education. (2019). 